Egyptian Journal of Aquatic Biology \& Fisheries

Zoology Department, Faculty of Science,

Ain Shams University, Cairo, Egypt.

ISSN $1110-6131$

Vol. 24(2): $69-82$ (2020)

www.ejabf.journals.ekb.eg

\title{
Isolation and cultivation of the freshwater amphipod Gammarus pulex (Linnaeus, 1758), with an evaluation of its chemical and nutritional content
}

\author{
Hamdy A. Abo-Taleb ${ }^{1 *}$, Amr F. Zeina ${ }^{1}$, Mohamed Ashour ${ }^{2}$, Mohamed M. Mabrouk ${ }^{3}$, \\ Ahmed E. Sallam ${ }^{2}$ and Mohamed MM. El-feky².
}

1- Faculty of Science, Al-Azhar University, Cairo, Egypt.

2- National Institute of Oceanography and Fisheries, Alexandria, Egypt.

3- Faculty of Agriculture, Al-Azhar University, Cairo, Egypt.

*Corresponding author: hamdy.ali.hamdy@gmail.com

\section{ARTICLE INFO}

Article History:

Received: Feb. 14, 2020

Accepted: March 18, 2020

Online: March 21, 2020

Keywords:

Gammarus pulex

Cultivation

Nutritional components,

Fish-farms,

Nests,

\section{INTRODUCTION}

In recent years, global aquaculture has increased significantly, and therefore the demand for animal protein used to feed farmed fish has increased, this has led to the search for other sources of animal protein instead of fish meal. Amphipods as Gammarus are among those possible alternatives due to its abundant productivity and appropriate nutritional content, as the current study showed that its protein content was $40 \%$, carbohydrates $27.4 \%$, fat $5.5 \%$, and it also contained antioxidants such as tannic acid (223.146 mg/100g) and $\beta$-carotene (21602.964 IU/100g) in addition to many essential vitamins in considerable values such as Vitamin B2 $338.3842 \mathrm{mg} / 100 \mathrm{~g}$, Vitamin B6 $(635.616 \mathrm{mg} / 100 \mathrm{~g})$, Vitamin B12 (419.5017 mg/100g), Vitamin A (19623.98 IU/100g), Vitamin E (177.958 $\mathrm{mg} / 100 \mathrm{~g})$, Vitamin D (59.672 mg/100g), and Folic Acid $(521.185 \mu \mathrm{g} / 100 \mathrm{~g})$.

Gammarus pulex has been isolated from the natural resource (Lake Mariout), and after 90 days of rearing in tanks (initial stock: 30 individuals/liter) supplied with four different types of nests: pored wood pieces, balls of palm fibers, balls of palm leaves, and balls of nylon net "Haba net", one type for each tank. The obtained data revealed that balls of palm leaves are the best nest for rearing as it gave the highest yields (127 individuals/liter), the average obtained numbers of the different rearing tanks was 108 individuals/liter with average wet weight $2.16 \mathrm{~g} / \mathrm{l}$, which means $1 \mathrm{~m} 3$ water can produce approximately $2160 \mathrm{~g}$ of Gammarus.

A new nutritional formula was used in the current study to feed the cultivated Gammarus in its various stages, which gave good results that were reflected in its productivity and the analysis of its chemical components.

Gammarus species amphipod crustaceans have widespread and very common worldwide, they are frequent and abundant in marine and freshwater, some species are 
characteristic of the surface waters (Sutcliffe, 1991) and others are benthic. Gammarid amphipods can be considered as the dominant macroinvertebrate (in abundance and biomass) in many freshwater ecosystems (Shaw, 1979; MacNeil et al., 1999) or marine water (Farrag $\boldsymbol{e t}$ al., 2019). They exhibit a range of feeding patterns including grazing, detritus feeding, predation including cannibalizing, while they are preferable prey for many other macroinvertebrates and fish (MacNeil et al., 1997; Wilhelm and Schindler, 1999). They have a principal position in the freshwater food webs for tearing and mixing all kinds of decomposing leaves remains, hence their classified as detritivores (Sutcliffe, 1991; Karlson et al., 2007). The mean brood of the freshwater Gammarus pulex increased from 6 eggs, in 6-7 mm females, to 29 eggs in 11-12 $\mathrm{mm}$ females. Gammarus contains a high level of protein and fats and appropriate values of the essential amino acid (Köprücü and Özdemir, 2005), as well as the Gammarus meal, enhances the feed intake in fish and increase its immune response, stress resistance and growth performance (Köprücü and Özdemir 2005; Rufchaei et al., 2017). Due to all these reasons, it is desirable to use this organism as a feed supplement in aquaculture although it is not yet been carried out in such industries (Harlıoğlu and Farhadi, 2018), and it can be used as an excellent and cheap alternative to fish meal in fish diets (Naylor et al., 2009). Gammarus was recently used as a substitute for animal protein in fish diets used to feed some of the most important high-value fish such as Caspian roach (Rufchaei et al., 2017), African jewelfish (Adhami et al., 2017), Siberian sturgeon (Razgardani Sharahi et al., 2016), Caspian salmon (Darhani et al., 2014), common carp (Navazandeh et al., 2013), rainbow trout (Azimi et al., 2011), and Nile tilapia (Köprücü and Özdemir 2005; Ashour et al., 2018).

The objective of the current study is to isolate and cultivate Gammarus pulex and determines the preferable nests that can use as habitat for these organisms in mass culture to improve its growth performance and biomass production and create suitable food mixture used in feeding these organisms. Additionally, analysis of their nutritional components to determine its suitability for use as an alternative to animal protein in fish diets. This work is considered to be the first of its kind, as an extensive culture of Gammarus under controlled conditions for commercial purposes has not yet been carried out, as indicated by Harlıoğlu and Farhadi (2018).

\section{MATERIALS AND METHODS}

\section{New feed mixture for the cultivated Gammarus}

Since the Gammarus feed on detritus, which includes leaves material that is decomposed by natural factors and microbial degradation, as well as leftovers of macroinvertebrate food as mentioned by Cummins and Klug (1979), Sutcliffe $\boldsymbol{e t}$ al. (1981) and Webster and Benfield (1986), while Moore (1975) noted that adults can be fed on algae. The young feed on organic matter (faeces of adults) (McCahonand Pascoe 1988b). Hence, the food used in the current study has been chosen with great care to suit what was previously mentioned, as well as to contain the nutrients necessary for high growth performance. The food mixture used in the present experiment is a new of its kind that was not previously used in feeding Gammarus or any of the other invertebrates. The 
nutritional mixture consists of $33.3 \%$ spirogyras algae, $33.3 \%$ berries leaves, $16.7 \%$ rice bran powder, and $16.7 \%$ soybean powder (1:1:0.5:0.5), respectively, the mixture was roughly mixed using a hand mixer (to produce coarse mixture).

\section{Conditioned process of the mixture}

To do these steps (Sutcliffe et al. 1981) was consulted and the following steps created:

- The dried mixture items have been mixed in the form of a coarse mixture.

- Organic water has been added to the mixture and left in indoor condition for 6 days to stimulus bacteria and fungi to do partial breakdown to the diet mixture.

- After 6 days the conditioned mixture used directly to feed the cultivated Gammarus.

\section{Feeding process}

Weighted quantities, 50g/1001 culture water, of feed were directly added manually two times a day. Siphonation was performed every two days to excluding the precipitations from the bottom of the tanks to prevent the anaerobic conditions.

\section{Collection and isolation of Gammarus}

Lake Mariout is one of the Egyptian northern lakes was chosen to collect Gammarus. A small plankton net with 200-micron mesh size was lowered vertically from bottom to surface and the benthic substrate just beneath the net was gently agitated before towing. Amphipods in the water and from the substrate have been collected in the net through dragging. Furthermore, all amphipods that are encountered were collected opportunistically.

The contents of the net were investigated, Gammarus was identified and isolated, while other invertebrates were carefully excluded. Gammarus were identified with a dissecting microscope and the collected specimens were separated into males and females and placed into plastic containers filled with lake water.

Then the Gammarus placed into 1001 transparent plastic holding containers filled with dechlorinated tap water (modified to be $8 \%$ salinity, like that in the wild) for $24 \mathrm{~h}$ acclimatization before starting the cultivation experiments.

\section{Cultivation conditions}

Cultivation conditions resembled what measured in the natural environment where the collected organisms were lived, and adjusted to be constant at all experiment tanks where $\mathrm{pH}$ was 7.8 , salinity was $8 \%$, the temperature was $27{ }^{\circ} \mathrm{C}$ and concentration of dissolved oxygen was $5.5 \mathrm{mg} / \mathrm{l}$. The rearing was in transparent tanks (51) 12-hour daylight and 12-hour fluorescent light tubes (600 lux). Oxygenation of the tanks was assured by air bubbling, aeration cause water agitation which helps in regular redistribution of the organisms overall the culture water body. $25 \%$ of water replacement was performed on a weekly scale.

The individuals of Gammarus pulex were moved and adapted in 1001 tanks contains dechlorinated tap water for 24 hours, then transferred and distributed on the culture tanks 
(51). The individuals have been stored at density 30 individual/liter (10 males "distinguished by visible genital papillae" and 20 females with fully developed oostegites with long fringed bristles which tangle together to form the brood pouch) for 90 days at environmental conditions resemble what measured in the wild where the species was collected.

Amphipods prefer to live and reproduce in nests contain pores and grooves and interstitial pathways as the habitats where they gathered. Hence we provided every cultivation tank with one different type of nests to determine which one is the preferable nest for the cultivation of this species. Four types of nests were used, one inside every single tank (pored wood pieces, balls of palm fibers, balls of palm leaves, and balls of nylon net "Haba net") three replicates for each type.

\section{Chemical and biological analysis}

\section{- Determination Physicochemical characters of the culture medium}

Water temperature was measured by using a mercury thermometer $110^{\circ} \mathrm{C}$ graduated to $0.1{ }^{\circ} \mathrm{C}$. The turbidity of water was measured by turbidimeter bench HACH $2100 \mathrm{~N}$ (SN 08040CO2711). Hydrogen ion concentration $(\mathrm{pH})$ values of the water were measured by using a digital $\mathrm{pH}$ meter levibond sensodirect $\mathrm{pH} 200 \mathrm{SN}$ (0814375). The dissolved oxygen was measured by DO-meter (HQ30d Flexi meter) HACH S.N 080600022236.

\section{- Analysis of bacterial and fungal content}

The bacterial content of the harvested Gammarus was analyzed to ensure that it was free of pathogens and its suitability for use in feeding fish larvae. The total count of bacteria in the yields was calculated and their contents of Salmonella, Clostridium, Listeria, and Escherichia coli were analyzed, as well as their Yeast and moulds content.

\section{- Analysis of vitamins and toxins content}

Vitamins B2, B6, B12, A, D, E, and folic acid, as well as the antioxidants as tannic acid and $\beta$-carotene contents, have been analyzed in the cultivated Gammarus to evaluate its nutritional value. On the other hand, the carcinogenic Aflatoxin has been analyzed to find out whether it is present in internationally permitted limits by the World Health Organization or not because it is one of the most dangerous known toxins, and therefore determine whether these organisms are actually valid for use in feeding of fish larvae or not.

\section{- Statistical analysis}

The obtained results were statistically analyzed using SPSS (version 20) for a oneway analysis of variance. Differences between individual treatments were tested with Duncan Multiple range test at a probability level of $0.05 \%$ when the test was significant.

\section{RESULTS}

After 90 days of Gammarus pulex rearing in four different types of nests: pored wood pieces, balls of palm fibers, balls of palm leaves, and balls of nylon net "Haba net". The obtained results showed that, as general, most of these individuals appear to have 
been mature because after 16 days the female's individuals had been produced two to five broods containing a mean of 13 eggs (range 8-27 eggs) resulted in a large number of offspring (average of 108 individuals/liter). Each month, irritation of the water in each cultivation tank has been done to ensure the organisms were distributed evenly and a random sample was taken to count the individuals in them to represent the number in liters. This process was done three times during three consecutive months. The highest density, mean of 127 individuals/l, was recorded from the tanks contain balls of palm leaves, while the lowest population density was recorded from that contains balls of palm fibers and pored wood pieces (Table 1).

Table 1. Average numbers of cultivated Gammarus (individuals/liter) at cultivation tanks contain different nests types

\begin{tabular}{lccccc}
\hline Days & Palm fibers & Palm leaves & Nylon net & Wood pieces & Average \\
\hline Day 0 & 30 & 30 & 30 & 30 & 30 \\
Day 30 & 44 & 75 & 63 & 50 & 58 \\
Day 60 & 76 & 106 & 95 & 79 & 89 \\
Day 100 & 92 & 127 & 115 & 98 & 108 \\
\hline
\end{tabular}

The nutritional content of Gammarus that was isolated was analyzed to determine its efficacy as food for fish larvae, as well as the difference between the concentrations of its contents from those used in other studies. The obtained data, in percentage, showed that the protein content of Gammarus pulex was 40 and fats were 5.5 while calories recorded 391.1 (Table 2).

Table 2. Nutritional values of Gammarus pulex (\% of its dry weight "DW")

\begin{tabular}{lc}
\hline Chemical compositions & Values \\
\hline Moisture \% & 5.7 \\
Crude protein (CP)\% & 40.0 \\
Ether extract (EE)\% & 5.5 \\
Ash \% & 21.4 \\
Total carbohydrate \% & 27.4 \\
Calories & 319.1 \\
Fibers\% & 2.9 \\
\hline
\end{tabular}

\section{Biomass and yields}

The average weight of the harvested individuals was $1 \pm 0.13 \mathrm{~g}$ wet weight $/ 50$ individuals. While the average harvest was 108 individuals/liter with average weight gain $2.16 \mathrm{~g}$ wet weight. The difference in the numbers of yields resulting in each treatment was reflected in the total biomass product (Table 3), where overall experiment period (90 days) the average amount of the harvest was ranged between $2.54 \mathrm{~g} / \mathrm{l}$ (tanks contain palm leaves) and 1.84 (palm fibers balls). The total average harvest from different tanks (5l tanks) was $2.16 \mathrm{~g} / \mathrm{l}$ (which means approximately $2160 \mathrm{~g}$ wet weight $/ \mathrm{m}^{3}$ ). 
Table 3. Monthly changing in average weight $(\mathrm{g} / \mathrm{l})$ at different experiments

\begin{tabular}{|c|c|c|c|c|c|}
\hline Days & Palm fibers & Palm leaves & Nylon net & Wood pieces & Average \\
\hline Day 0 & \multicolumn{4}{|c|}{0.6} & 0.6 \\
\hline Day 30 & 0.88 & 1.5 & 1.26 & 1 & 1.16 \\
\hline Day 60 & 1.52 & 2.12 & 1.9 & 1.58 & 1.78 \\
\hline Day 100 & 1.84 & 2.54 & 2.3 & 1.96 & 2.16 \\
\hline
\end{tabular}

\section{Microbial content}

Analysis of the bacterial content of the harvested Gammarus showed a total bacterial count $>6500 * 10^{2} \mathrm{CFU} / \mathrm{gm}$, while the harvest has no dangerous bacteria like Salmonella sp., Clostridium sp., and Escherichia coli, while Listeria sp. was found in a relatively low count, 65 CFU/gm (Table 4).

Table 4. Total bacterial count and content of the harvest from pathogenic bacteria, as well as yeast and moulds (CFU is a colony-forming unit that means: the number of viable bacteria or fungal cells in a sample)

\begin{tabular}{ll}
\hline Item & \multicolumn{1}{c}{ Count } \\
\hline Total bacterial count & $>6500^{*} 10^{2} \mathrm{cfu} / \mathrm{gm}$ \\
E.coli & $0.0 \mathrm{CFU} / \mathrm{gm}$ \\
Yeast \& molds & $0.0 \mathrm{CFU} / \mathrm{gm}$ \\
Salmonella & $0.0 \mathrm{CFU} / 25 \mathrm{gm}$ \\
Clostridium & $0.0 \mathrm{CFU} / 25 \mathrm{gm}$ \\
Listeria & $65 \mathrm{CFU} / \mathrm{gm}$ \\
\hline
\end{tabular}

Vitamins and toxins content

The obtained results showed that the farmed Gammarus pulex contained most of the vitamins necessary for the growth and improvement of the health status of fish larvae as they contained vitamins B2, B6, B12, A, D, E and folic acid in high proportions. It contains high values of the antioxidants tannic acid and beta-carotene, respectively. It was also observed that these organisms contain low levels, $6.933 \mathrm{ppb}$, of the toxic compound aflatoxin (Table 5).

Table 5. Different values of vitamins, antioxidants, and aflatoxin inside Gammarus pulex.

\begin{tabular}{ll}
\hline Items & \multicolumn{1}{c}{ Values } \\
\hline Vitamin B2 & $338.3842 \mathrm{mg} / 100 \mathrm{~g}$ \\
Vitamin B6 & $635.616 \mathrm{mg} / 100 \mathrm{~g}$ \\
Vitamin B12 & $419.5017 \mathrm{mg} / 100 \mathrm{~g}$ \\
Vitamin A & $19623.98 \mathrm{IU} / 100 \mathrm{~g}$ \\
Vitamin E & $177.958 \mathrm{mg} / 100 \mathrm{~g}$ \\
Vitamin D & $59.672 \mathrm{mg} / 100 \mathrm{~g}$ \\
Folic Acid & $521.185 \mu \mathrm{g} / 100 \mathrm{~g}$ \\
$\beta$-carotene & $21602.964 \mathrm{IU} / 100 \mathrm{~g}$ \\
Tannic acid & $223.146 \mathrm{mg} / 100 \mathrm{~g}$ \\
Aflatoxin B1 & $6.933 \mathrm{ppb}$ \\
\hline
\end{tabular}




\section{DISCUSSION}

For a successful culture of this type of macroinvertebrate, a brief reference should be made to its life cycle. The Gammarus undergoes an impressive reproductive cycle that begins when the male (larger than the female unlike all other arthropods) began to hold several females before deciding which one will carry the most eggs (Dick and Elwood 1996; Zielinski 1998). After the male determines the appropriate female, and holds it using his first pair of gnathopods in the lower side of his body and parallels to him (Borowski, 1984) and becomes responsible for the movement (Bollache and Cezilly, 2004). The pair stay in this position for up to 2 weeks as a precopula stage (Hartnoll and Smith, 1980), mating occurs as soon as the female sheds her skin, the pair is separated after mating where the female becomes carries the developing eggs in her brooding pouch. After 1 to 3 weeks, the eggs hatch juveniles which remain in the brooding pouch 4-6 weeks until the next moult for the mother female. Then the young go out of the brooding pouch to swim away from the mother, the first food for the young is faeces of adults (coprophagy) (McCahonand Pascoe, 1988b). The nutrition type gradually turns into conditioned leaves and detritus, which becomes the main nutrition after about a month. These young reach sexual maturity after 10 moults that take 90-120 days (approximately 3-4 months) (McCahon and Pascoe, 1988a). The average age of Gammarus is from one to two years.

The idea of this study raised from the facts that Gammarus is a cheap protein source in comparison to fishmeal and as it a live food characterized by high nutritional value (Harlığlu and Farhadi, 2018), besides, Köprücü and Özdemir (2005), Rufchaei et al. (2017) confirmed that using these organisms as a feed supplement for fish has a great impact on increasing their feed intake and enhancing the immune response, hence additional studies on the rearing and cultivation of Gammarus sp. should be conducted in large scale.

To create the new food needed to feed cultured Gammaus, the former researchers' experiences and observations were consulted, where Sutcliffe et al. (1981) stated that Gammaus could feed on conditioned plant leaves with organic water or leaves that had partial microbial degradation (Cummins and Klug, 1979). McCahon and Pascoe (1988b) noted that the young feed on the faeces of adults, and accordingly a new nutritional formula was made as the water in the fish farms ponds was used as organic water, dried berries leaves were crushed as well as dried spirogyra algae and put them in this organic water for six days and adding powder soybean and rice bran to make a conditioned mixture that used directly in feeding the Gammarus, and thus we had obtained a mixture suitable for the individuals of all sizes and ages. The cultured Gammarus is harvested using nets with holes of varying sizes, so the larger individuals harvested to use as feed additives and the small sizes returned to the culture ponds again. 
There is a severe lack of data about the culture of Gammarus as only a few publications are detailing G. pulex culture include McCahon and Pascoe (1988a; 1988b) and the later Bloor (2009) in addition to a review of Kunz et al. (2010) who confirmed the lack of publications except the previously mentioned ones. The plastic containers that supplied with aerated dechlorinated tap water and illumination periods 12 hours by artificial light was previously used in this purpose by Sutcliffe $\boldsymbol{e t}$ al. (1981) and Kunz $\boldsymbol{e t}$ al. (2010), the authors used conditioned common leaves for feeding the cultivated Gammarus, this feeding procedure is the only known method used by (Kaushik and Hynes, 1971; Willoughby and Sutcliffe, 1976) for feeding the adults.

In the present study, most of the collected Gammarus individuals appear to have been mature because after 16 days of cultivation the female's individuals had been produced two to five brood pouches containing a mean of 13 eggs (range 8-27 eggs) resulted in a large number of offspring (average of 108 individuals/liter). This result was resembled what reported by Kunz et al. (2010), who mentioned that 200 visibly gravid G. pulex females and 100 precopula can produce 500-1000 newly hatched individuals after 5 days. Youngsters begin feeding on the faeces of adults and after 25 days they turn completely into nutrition as adults on the conditioned leaves of the plant. We assumed that the individuals were mature in the wild before the cultivation because of the freshwater Gammarus almost mature after an average of 90-120 days (Hynes, 1955; Welton and Clarke, 1980). Selective harvesting large sizes is a stressful and timeconsuming process that carries benefits as it gives an opportunity to growth of the young as well as improving the characteristics of the culture environment and. This procedure was conducted by McCahonand Pascoe (1988a) on laboratory cultivated Gammarus. The young Gammarus can be distinguished from adults as juveniles possess a primary flagellum of each antenna consists of five segments, the number of these segments increases with age and growth, reaching 14-16 segments after 10 moults (McCahon and Pascoe, 1988b).

Data revealed that among the four used nests, the balls of palm-leaf nests were preferable for rearing as it gave the highest yields (127 individuals/liter), this may be because these mesoherbivores natural behaviour is built their nests by rolling up a selected plant leaves into tubes as reported by Barnard et al. (1991) and Fukui (2001). The nest-building behaviour for these organisms has been first reported by Holmes (1901) and then by Skutch (1926). These publications revealed that the nest as being connected together by silk threads surround the used leaves that are secreted from special glands in the pereopods. Additionally, in the current study, the palm leaves nest differs from the other three nests since it composed of leaves that can be used by the organisms in the feeding, this may be a reason why the tanks contain palm leaves nests gave the highest Gammarus productivity. This may be confirmed by Jones (1971), Griffiths 
(1979), Poore and Steinberg (1999) who reported that most amphipods consume the algal tissues that build up the walls of their nests.

The time taken to reach sexual maturity for Gammarus pulex is influenced by temperature; in the present experiment maturity time taken 16 days at $27^{\circ} \mathrm{C}$, while it takes 120 days at $15-20{ }^{\circ} \mathrm{C}$ (Hynes, 1955), 130 days at $13{ }^{\circ} \mathrm{C}$ (McCahon and Pascoe, 1988b), and 133 days at $15^{\circ} \mathrm{C}$ (Welton and Clarke, 1980). Harlıoğlu and Farhadi (2018) reported that "by increasing rearing temperature and providing excess food, it is possible to culture animals throughout the year and attains a reduced time to sexual maturity".

In the present study, chemical analysis of the present species indicated that it contains $40 \%$ protein, $5.5 \%$ lipid, $27.4 \%$ carbohydrate, $21.4 \%$ ash, $2.9 \%$ fibers, $3191 \mathrm{cal} / \mathrm{g}$ energy, and 5.7 moisture. The values of protein and carbohydrates are in the range of recorded values for the chemical content of different Gammarus species in previous studies (Mathias et al., 1982; Seyfabadi et al., 2004; Köprücü and Özdemir, 2005; Alavi Yeganeh et al., 2008; Shamsaei and Khodami, 2009; Azimi et al., 2011; BaezaRojano et al., 2014) as reported by Harlıoğlu and Farhadi (2018) where the protein content was varied between 40-45\%, lipid was 5-10\%, 25-35\% ash, and 2700-3500 cal/g energy. While the value of carbohydrates was $6-15 \%$, which is a lower value than recorded in our study, perhaps this difference is due to the diet used in the current study, as it contained rice bran and soy powder, which are known to contain carbohydrates in high proportions. Additionally, several factors can affect the chemical composition of Gammarus as enumerated by Harlığlu and Farhadi (2018) which include age, habitats, season, region, life stage, and drying process after harvesting.

Gammarus is a very suitable food that provide the protein requirements for fish larvae in the early stages of life than large fish $(2-3 \mathrm{~cm})$ (Mathias et al., 1982). The aflatoxin B1 value within the cultivated Gammarus was very low, $6.933 \mathrm{ppb}$, it less than the permitted values of the United States Food and Drug Administration which ranged from 20-300 ppb (FDA, 2013). Its content of aflatoxin B1 is resembled what measured by El-feky and Abo-Taleb (2020) for another cultivated crustacean Daphnia magna.

These organisms also contained high levels of the most important vitamins, as well as two of the most important antioxidants, tannic acid, and beta-carotene, additionally, these organisms are considered free from many pathogenic bacteria, which makes the use of these organisms as food for fish very beneficial and safe for animals and human health.

\section{CONCLUSION}

Based on the obtained data in the current work, Gammarus pulex is one of the most important invertebrates has high levels of protein and other nutritional content that is recommended for use as a partial replacement for fish meal in feeding fish larvae. Also, many nutrients of low economic value can be used to form a mixture used for feeding these organisms in mass culture. It is preferable to supply the culture with nests characterized by the presence of holes and interstitial pathways, as well as composed of plant leaves materials like palm leaves to improve the cultured Gammarus production. 


\section{ACKNOWLEDGEMENT}

The researchers extend their sincere thanks to the Egyptian Ministry of Higher Education and Scientific Research for its continuous support, and all the results in the current research are some of the outputs of a project funded from the budget of the Minister of Scientific Research office (a project of national strategy program for genetic engineering and biotechnology, phase III).

\section{REFERENCES}

A.O.A.C. (1990). Official methods of analysis, $16^{\text {th }}$ edition. AOAC, Arlington, Virginia.

Adhami, B.; Yeganeh, S. and Kenari SJ. (2017): Influence of Caspian Gammarus on growth parameters, survival and serum biochemical factors in jewel fish (Hemichromis bimaculatus). Exp. Anim. Biol., 19: 31-37 (In Persian with English abstract)

Alavi Yeganeh, M.S.; Abedian Kenari, A.M. and Rezaii, M. (2008): Effect of Gammarus powder as a supplementary diet on growth and survival of rainbow trout larvae (Oncorhynchus mykiss). Pajouhesh \& Sazandegi, 77:113-123 (In Persian with English abstract).

Ashour, M.; Abo-Taleb H.A.; Abou-Mahmoud M.M. and El-Feky M.M. (2018): Effect of the integration between plankton natural productivity and environmental assessment of irrigation water, El-Mahmoudia Canal, on aquaculture potential of Oreochromis niloticus. Turk. J. Fish. Aquat. Sc., 18:1163-1175.

Azimi, A.; Hosseini, S.A. and Sudagar, M. (2011): Effect of replacement of Caspian Sea Gammarus meal by partial kilka fish meal on growth performance, feed conversion ratio and survival of juveniles of rainbow trout (Oncorhynchus mykiss). Iran. Fish. Sci. J., 20: 63-74 (In Persian with English abstract).

Baeza-Rojano, E.; Hachero-Cruzado, I. and Guerra-García, J.M. (2014): Nutritional analysis of freshwater and marine amphipods from the strait of Gibraltar and potential aquaculture applications. J. Sea Res., 85: 29-36.

Barnard, J.L.; Sandved, K. and Thomas, J.D. (1991): Tube-building behaviorin Grandidierella, and twospeciesof Cerapus. Hydrobiol., 223: 239-254.

Bloor, M. (2009): Aquatic pollution: Case study of landfill leachate toxicity and remediation. VDM Verlag, Germany pp. 1-176. ISBN 978-3-639-14699-8.

Bollache, L. and Cezilly, F. (2004): State-dependent pairing behaviour in male Gammarus pulex (L.) (Crustacea, Amphipoda): effects of time left to moult and prior pairing status. Behav. Process., 66: 131-137.

Borowski, B. (1984): The use of the males' gnathopods during precopulation in some gammaridean amphipods. Crustaceana, 47:245-250.

Cummins, K.W. and Klug M.J. (1979): Feeding ecology of stream invertebrates. Ann. Rev. Ecol. Syst., 10:147-172. 
Darhani, M.; Mohammadi, M. and Shamsaei, M., et al (2014): Investigation on the effects of live and commercial food on growth and survival rate of Caspian Salmon (Salmo trutta caspius). Breed. Aquacult. Sci. Qr, 2: 23-34

Dick, J.T.A. and Elwood, R.W. (1996): Effects of natural variation in sex ratio and habitat structure on mate-guarding decisions in amphipods (Crustacea). Behav. Process., 133: 985-996.

El-feky, M.M. and Abo-Taleb, H.A.(2020): Effect of feeding with different types of nutrients on intensive culture of the water flea, Daphnia magna Straus, 1820. Egypt. J. Aquat. Biol. Fish., 24(1): 655-666

Farrag, M.M.; El-Naggar, H.A.; Abou-Mahmoud, M.M.; Alabssawy, A.N.; Ahmed H.O.; Abo-Taleb H.A. and Kostas, K. (2019): Marine biodiversity patterns off Alexandria area, southeastern Mediterranean Sea, Egypt. Egypt. Environ. Monit. Assess., 191: 367.

Fukui, A. (2001): Indirect interactions mediated by leaves shelters in animal-plant communities. Popul. Ecol., 43: 31-40.

Griffiths, C.L. (1979): A redescription of the kelp curler Ampithoe humeralis from South Africa and its relationship with Macropisthopous. Ann. S. Afr. Mus., 79: 131-138.

Harlıŏlu, M. and Farhadi, A. (2018): Importance of Gammarus in aquaculture. Aquac. Int., 26: 1327-1338.

Hartnoll, R.G. and Smith M. (1980): An experimental study of sex discrimination and pair formation in Gammarus duebeni. Crustaceana, 38:253-264.

Holmes, S.J. (1901): Observations on the habits and natural history of Amphithoe longimana Smith. Biol. Bull., 2: 165-193.

Hynes, H.B.N. (1955): The reproductive cycle of some British freshwater Gammaridae. J. Anim. Ecol., 24:352-387.

Jones, L.G. (1971): Studies on selected small herbivorous invertebrates inhabiting Macrocystis canopies and holdfasts in southern California kelp beds. Pp. 343-367 in The Biology of Giant Kelp Beds (Macro- cystis) in California, W. J. North, ed. Series: Nova Hedwigia 32. J. Cramer, Lehre, Germany.

Karlson, K.; Bonsdorff, E. and Rosenberg, R. (2007): The impact of benthic macrofauna for nutrient fluxes from Baltic Sea sediments. AMBIO: A. J. Hum. Environ., 36: 161-167.

Kaushik N.K., Hynes H.B.N. (1971): The fate of dead leaves that fall into streams. Arch Hydrobiol., 68: 465-515.

Köprücü, K. and Özdemir, Y. (2005): Apparent digestibility of selected feed ingredients for Nile tilapia (Oreochromis niloticus). Aquaculture, 250: 308-316.

Kunz, P.Y.; Kienle, C. and Gerhardt, A. (2010): Gammarus spp. in aquatic ecotoxicology and water quality assessment: toward integrated multilevel tests. In Reviews of Environmental Contamination and Toxicology Volume 205 (pp. 1-76). Springer New York. 
MacNeil, C.; Dick, J.T.A. and Elwood, R.W. (1997): The trophic ecology of freshwater Gammarus spp. (Crustacea: Amphipoda): problems and perspectives concerning the functional feeding group concept. Biol. Rev., 72: 349-364.

MacNeil, C.; Dick, J.T.A. and Elwood, R.W. (1999): The dynamics of predation on Gammarus spp. (Crustacea: Amphipoda). Biology Review 74: 375-395. Marchant, R., and H. B. N. Hynes. 1981. The distribution of Gammarus pseudolimnaeus (Crustacea: Amphipoda) along a reach of the Credit River, Ontario. Freshw. Biol., 11: 169-182.

Mathias, J.A; Martin, J.; Yurkowski, M.; Lark, J.G.I.; Papst, M. and Tabachek, J.L. (1982): Harvest and nutritional quality of Gammarus lacustris for trout culture. Trans. Am. Fish. Soc., 111: 83-89.

McCahon, C.P. and Pascoe, D. (1988a): Culture techniques for three freshwater macroinvertebrate species and their use in toxicity tests. Chemosphere, 17: 24712480 .

McCahon, C.P. and Pascoe, D. (1988b): Use of Gammarus pulex (L.) in safety evaluation tests: Culture and selection of a sensitive life stage. Ecotoxicol. Environ. Saf., 15: 245-252.

Moore, J.W. (1975): The role of algae in the diet of Asellus aquaticus L. and Gammarus pulex L. J. Anim. Ecol., 44: 719-730.

Navazandeh, A.Z.; Yousefian, M. and Hedayatifar, M. et al (2013): Effect of Gammarus meal and different enzymes on growth performance and biochemistry of Cyprinus carpio larvae. Breed. Aquacult. Sci. Qr., 1:79-90 (In Persian with English abstract).

Naylor, R.L.; Hardy, R.W.; Bureau, D.P.; Chiu, A.; Elliott, M.; Farrell, A.P.; Forster, I.; Gatlin, D.M.; Goldburg, R.J.; Hua, K. and Nichols, P.D. (2009): Feeding aquaculture in an era of finite resources. Proc. Natl. Acad. Sci., 106: $15103-15110$

Poore, A.G. and Steinberg P.D. (1999): Preference-performance relationships and effects of host plant choice in a herbivorous marine amphipod. Ecol. Monogr., 69: 443-464.

Razgardani Sharahi, A.; Falahatkar, B. and Efatpanah I. (2016): Effect of fish meal replacement with Gammarus meal on growth and body composition of juvenile Siberian sturgeon, Acipenser baerii (Brandt, 1869). J. Aquat. Ecol., 6: 102-113 (In Persian).

Rufchaei, R.; Hoseinifar, S.H.; Mirzajani, A. and van Doan, H. (2017): Dietary administration of Pontogammarus maeoticus extract affects immune responses, stress resistance, feed intake and growth performance of Caspian roach (Rutilus caspicus) fingerlings. Fish Shellfish Immun., 63:196-200.

Seyfabadi, S.J.; Negarestan, H. and Moghadasi, B. (2004): Chemical components of amphipod, Pontogammarous meoticus, along the southern coast of the Caspian Sea. J Mar Sci Technol 3:51-56 (In Persian with English abstract). 
Shamsaei, M.M. and Khodami, S. (2009): The effects of different drying methods on quality and food factor of Gammarus (Pontogammarous meoticus). J.fish., 5:1-12 (In Persian with English abstract).

Shaw, G. (1979): Prey selection by breeding dippers. Bird Study 26: 66-67. Taylor, S. J., and D. W. Webb. 2000. Subterranean Amphipoda (Crustacea) of Illinois' Salem Plateau: spatial and temporal components of microdistribution. Illinois Nat. Hist. Survey Techni Rep. INHS., 2000 27: 1-62

Skutch, A.F. (1926): On the habits and ecology of the tube-building amphipod Amphithoe rubricata. Ecology, 7: 481-502.

Sutcliffe, D.W. (1991): Reproduction in Gammarus (Crustacea, Amphipoda): Basic processes. Freshw. Forum, 2: 102-128.

Sutcliffe, D.W.; Carrick, T.R. and Willoughby, L.G. (1981): Effectsof diet, body size, ageand temperatureon growthrates in the amphipod Gammarus pulex. Freshw. Biol., 11: 183-214

Webster, J.R. and Benfield, E.F. (1986): Vascular plant breakdown in freshwater ecosystems. Ann. Rev. Ecol. System., 17: 567-594.

Welton, J.S. and Clarke, R.T. (1980): Laboratory studies on the reproduction and growth of the amphipod, Gammarus pulex (L.). J. Anim. Ecol., 49:581-592.

Wilhelm, F.M. and Schindler, D.W. (1999): Effects of Gammarus lacustris (Crustacea: Amphipoda) on plankton community structure in an alpine lake. Canadian. J. Fish. Aquat. Sci., 56: 1401-1408.

Willoughby, L.G. and Sutcliffe, D.W. (1976): Experiments on feeding and growth of the amphipod Gammarus pulex (L.) related to its distribution in the River Duddon. Freshw. Biol., 6:577-586.

Zielinski, D. (1998): Life cycle and altitude range of Gammarus leopoliensis Jazdzewski \& Konopacka, 1989 (Amphipoda) in south-eastern Poland. Crustaceana, 71:129-143. 


\section{ARABIC SUMMARY \\ عزل واستزراع أحد أنواع مزدوجات أرجل المياه العذبة (Gammarus pulex) فى الموائل المختلفة مع تقييم محتواها الكيميائي والتظذوي التئي

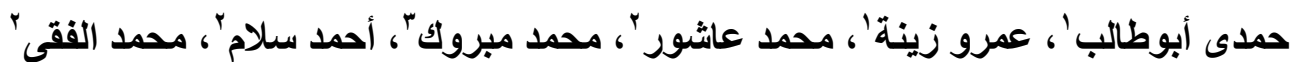

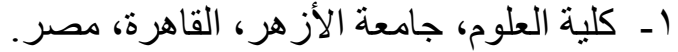

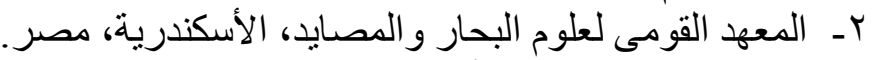

$$
\begin{aligned}
& \text { بـ كلية الزر اعة، جامعة الأزهر ، القاهرة، مصر. }
\end{aligned}
$$

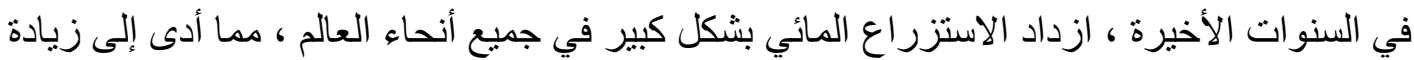

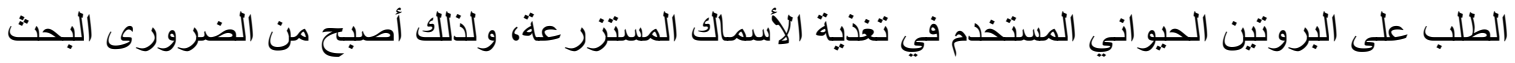

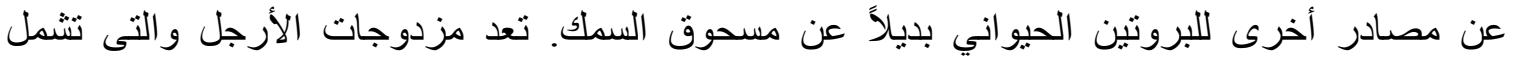

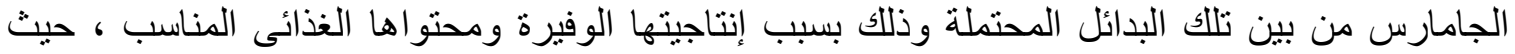

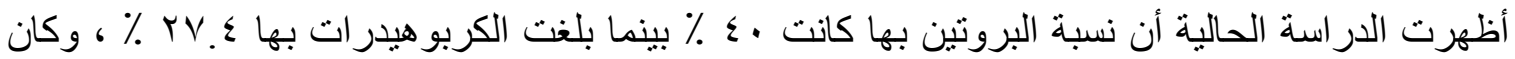

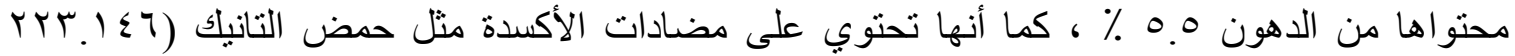

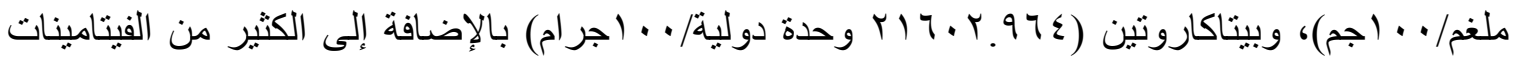
الأساسية مثل فيتامين بr (

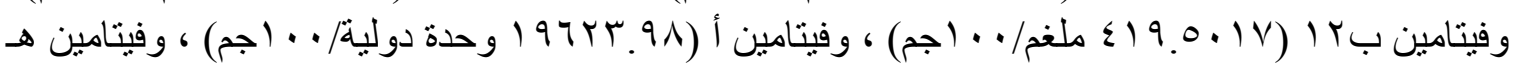

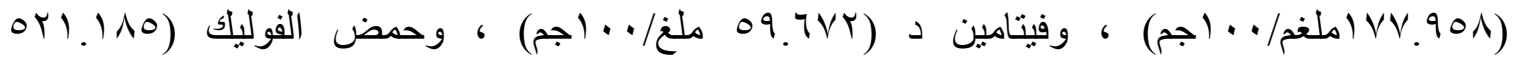

$$
\text { ميكرو غرام/ • • (جم). }
$$

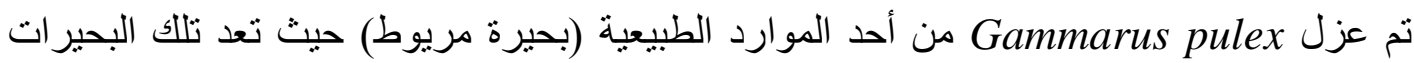

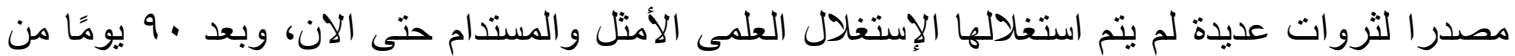

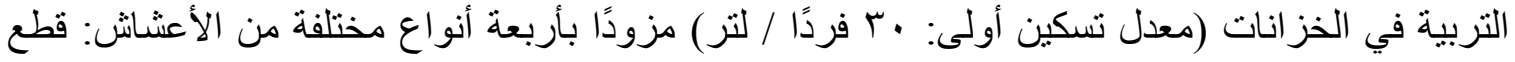

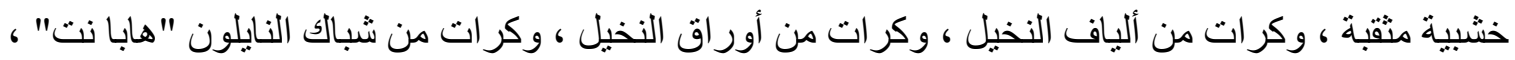

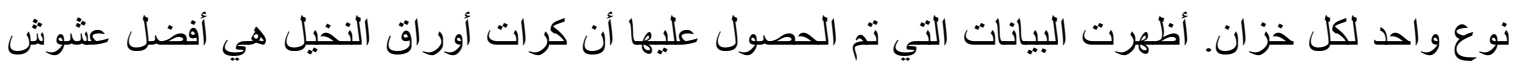

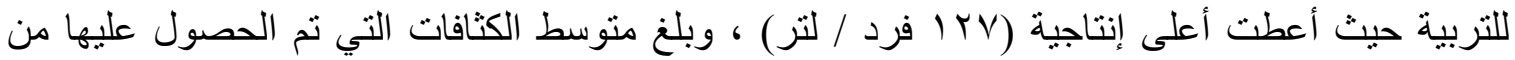

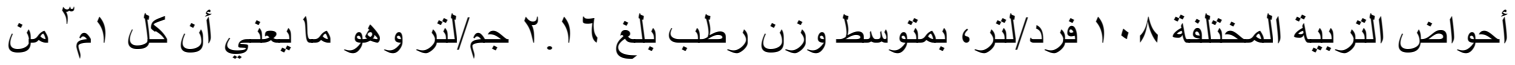

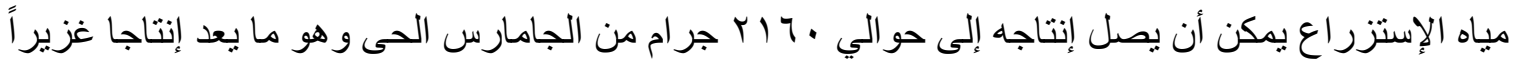
يمكن أن يفى كبديل جزئى فعّال لمسحوق السمك إنى في علائق الأسماك. 